\section{Perspectives on urban conditions and population health}

\author{
Perspectivas sobre condições urbanas \\ e saúde da população
}

\author{
1 Center for Urban \\ Epidemiologic Studies, \\ New York Academy of \\ Medicine, New York, U. S. A. \\ 2 Department of \\ Epidemiology, Johns \\ Hopkins University, \\ Bloomberg School of Public \\ Health, Baltimore, U. S. A. \\ 3 Department of \\ Epidemiology, Columbia \\ University, Mailman \\ School of Public Health, \\ New York, U. S. A. \\ 4 Program in Urban Public \\ Health, Hunter College, \\ City University of New York, \\ New York, U. S. A. \\ Correspondence \\ D. Vlahov \\ Center for Urban \\ Epidemiologic Studies, \\ New York Academy \\ of Medicine. 1216 Fifth \\ Avenue, New York, NY, USA \\ 10029-5283. \\ dvlahov@nyam.org
}

\begin{abstract}
The majority of the world's population will live in cities in the next few years and the pace of urbanization worldwide will continue to accelerate over the coming decades. While the number of megacities is projected to increase, the largest population growth is expected to be in cities of less than one million people. Such a dramatic demographic shift can be expected to have an impact on population health. Although there has been historic interest in how city living affects health, a cogent framework that enables systematic study of urban health across time and place has yet to emerge. Four alternate but complementary approaches to the study of urban health today are presented (urban health penalty, urban health advantage, urban sprawl, and an integrative urban conditions model) followed by three key questions that may help guide the study and practice of urban health in coming decades.
\end{abstract}

Cities; Urbanization; Urban Health
David Vlahov 1,2,3

Sandro Galea 1,3

Emily Gibble 1

Nicholas Freudenberg 4

\section{Introduction}

The majority of the world's population will live in cities in the next few years and the pace of urbanization worldwide will continue to accelerate over the coming decades, particularly in Latin America, Asia, and Africa 1. According to United Nations 2000 forecasts, by the year 2030 the world's population will increase $30 \%$ to have an additional 2 billion persons more than today. Of these, fully 1.9 billion are expected to reside in the cities and towns of Latin America, Asia, and Africa 2.

Interest in the study of urban health, or how cities affect health, has waxed and waned over the past few decades. In the first half of the twentieth century, researchers focused attention on the relationship between characteristics of the urban environment and health 3,4 . More recently, scientists and policy makers have made new efforts to understand how social and economic factors that are exogenous to the individual shape health 5,6,7. Some of this thinking can usefully be applied to the study of the health of urban populations.

Cities are more than the aggregation of people with individual risk factors and health care needs; here we argue that factors beyond the individual, including the social and physical environment and systems of health and social services are the primary determinants of the health of urban populations 8 . In this paper we 
first briefly discuss the evolution of thought about health in cities, summarize four alternate approaches to the study of urban health today, and propose three key questions that may help guide the study and practice of urban health in coming decades.

\section{Historical perspectives on health in cities}

Researchers from various disciplines have long considered how cities shape health to be an important area of inquiry. For much of European history, most scholars considered cities (or urban living) to be detrimental to health and in many areas cities were characterized by features unquestionably linked to poor health 9 . In 19th century Europe and America, for example, infectious diseases were rife and have been attributed to unsafe water, improper waste management especially with poor drainage and unpaved streets, poor food handling, crowded unventilated housing, and a concentration of foreign and domestic commerce that provided introduction of pathogens especially in port cities 10,11. As cities assumed a greater role in the life of European countries, population density, numbers of marginalized populations, pollution, and crime frequently led to deteriorating health and unfavorable comparisons with non-urban areas $11,12,13,14$. Some have noted that the rate of urbanization rather than city size was a more powerful predictor of mortality, presumably since this was an indicator of population influx outstripping resources 10. Although published data are less readily available, health in cities was also worse than it was in non-urban areas in Asia 15,16.

While an emerging group of public health practitioners in the $18^{\text {th }}$ and 19th centuries were beginning to make connections between urban living conditions, health, and disease 17 , social theorists were articulating how social and economic factors external to the individual could play a role in shaping individual well-being 18,19. For example, Rousseau contributed an appreciation of the role of place and institutions in shaping health and well-being 18. Durkheim provided influential insights into the role of norms and the function of society coincident with the growth of urban living and industrial conditions in cities in the 19th century 19. Contemporaneously, Tonnies, a German sociologist, described the rural-urban transition and the increasing unpredictability of urban life that he postulated had an effect on mental and physical health 20. The fiction of Charles Dick- ens (1850) 21 and the sociological analysis of Engels (1968) 22 provided different perspectives on the living conditions and health of the English working class.

By the early 20th century, however, the urban environment in many cities in wealthier countries had improved dramatically, as had the health of urban populations. The sanitary movement was considered responsible for widespread improvements in urban conditions in many European and North American cities $11,17,23$. More recent analyses suggest that improvement in survival among urban residents was due both to sanitary reforms such as paved streets, construction of sewers, disinfection of water, pasteurization, and also surveillance and quarantine or isolation of sick individuals 24. From an epidemiologic evolutionary perspective, changes in virulence of infections (e.g., scarlet fever) and progressively more immunized populations also contributed 10. In Europe, one historical analysis showed that for much of the 19th century infant mortality rates in Imperial Germany were higher in urban as compared to non-urban areas. However, with sanitary reforms, infant mortality rates in urban areas declined dramatically in the 1870 s and later fell in the rest of the country 25 . Today, health is better in cities than in rural areas in many of the wealthier countries, although cities are still the site of sharp inequalities in health.

\section{Health in Latin American cities}

Several urban features, while not unique to Latin America, characterize the specific health challenges facing cities on this continent. First is the growth of mid-size cities such as El Alto, a city of more than 500,000 in Bolivia, Manaus in Brazil, or Temuco in Chile. Often such cities are growing at a faster pace than mega-cities, and have fewer resources to cope with their growing pains. Providing clean water, sanitation, adequate housing, and accessible health care to existing residents as well as new migrants poses a significant test for municipal and public health officials 26 . A related problem is the growth of periurban settlements known as favelas in Brazil, pueblos jovenes in Peru, or ranchos in Venezuela. In Mexico City, almost half the city's population lives in such spontaneous settlements, where sanitation, education, employment, health services, and links to the formal urban economy are often precarious 27 .

Second, while infectious diseases such as tuberculosis, HIV, and malaria remain critical health issues in developing-country cities, the 
epidemiologic transition has been accompanied by an increase in the risk of chronic disease (such as obesity) and increasingly, accidents and injuries (motor vehicle accidents, homicide, and violence) are accounting for a substantial proportion of morbidity and mortality in Latin American cities. As in many other parts of the world, rates of obesity and overweight are increasing in Latin America, but at the same time many countries face what has been called the "double disease burden" - the unresolved problem of malnutrition caused by nutritional deficits 28,29 . In addition, motor vehicle accidents and homicide and violence are 2 of the 5 leading causes of death in Mexico's urban areas 30 . Pedestrian injuries over a threeyear period in Mexico City were three times those of Los Angeles 31. Factors associated with pedestrian injuries in Mexico City included poverty, inattention to risky conditions, insufficient public investment in traffic lights, and the dangerous mix of industrial, commercial, and private traffic.

Latin America has the world's highest homicide rate ( 7.7 per 1,000 population), more then twice the world average of 3.5 per $1,00030,32$. Violent crime is particularly prevalent in Latin America's large cities, disproportionately affecting men living in low-income neighborhoods 33,34. Gender roles and relations put men and women at risk of different types of violence 35 .

Mental health also contributes to substantial morbidity in Latin American cities 36,37. For example, Harpham et al. 38 studied depression and anxiety among adolescents in Cali, Colombia; girls were three times more likely than boys to exhibit signs of ill health. Risk factors for ill health included being female, having no schooling or incomplete primary (relative to secondary) education, the existence of family violence, being a victim of violence, and perceptions that violence affects the community. Other research suggests that the rapid urbanization and periurban settlements that characterize Latin American cities may put a strain on the social support systems that can serve as a buffer against mental health problems 39 .

Finally, in Latin America, as elsewhere, globalization has raised new questions about the well-being of cities. Defenders cite its contribution to economic growth, employment, and the integration of Latin American cities into the world economy 40 , trends they believe will in the long term improve living conditions and health. Critics claim that globalization has contributed to urban inequality and unsustainable development and that the neoliberal agenda of deregulation and privatization has reduced access to health care, damaged public health infrastructures, and led to deterioration in the living conditions of vulnerable urban populations 41,42 .

\section{Approaches to urban health}

Renewed interest in urban health has sparked the development of new or revitalized, albeit sometimes contradictory, frameworks for understanding the impact of city living on health. Two approaches, "urban health penalty" and "urban sprawl", focus on the health problems of cities 43; a third approach, "urban health advantage", considers the special resources and protective effects of cities. Finally, the "urban living conditions" model is an attempt to synthesize these approaches by considering the interacting influences that shape the urban living conditions that determine health.

The "urban health penalty" approach posits that cities concentrate poor people and expose residents to unhealthy environments leading to a disproportionate burden of poor health, especially in what some have called "inner cities" 44 . In the past 50 years, the departure of the middle class and jobs to the surrounding suburbs in the United States as well as other developed countries has led to intense urban poverty and increased racial segregation, leaving cities with diminished capacity to meet the needs of increasingly impoverished populations 45 . By the late $20^{\text {th }}$ century, the U.S. and some European cities had higher rates than their respective non-urban areas of HIV infection, substance abuse, mental illness, infant mortality, asthma, and other conditions 46 . These disparities led to a resurrection of the earlier concept of "urban health penalty" 8,46. The "urban health penalty" rubric draws specific attention to the poor health conditions that persist in many inner cities 47 , describes the resulting inequalities in health 48 , and points to the necessity of improving health conditions particularly among disadvantaged urban populations. However, this approach tends to equate "urbanness" with issues of disadvantage, and urban health becomes synonymous with conditions among the minority poor of the inner cities. In so doing, this approach fails to recognize that cities have many positive aspects, such as high levels of social support and accessible health care. In addition, this approach does not consider the specific characteristics of cities that may be associated with poor health nor the many factors in addition to poverty that account for urban population health. 
More recently, public health, urban planning, and environmental researchers have focused attention on "urban sprawl", a concept that considers the consequences of the diffusion of urban populations outside central cities. Motivated by the rapid suburbanization of U.S. and European cities, this approach highlights the adverse health effects of urban growth into outlying areas, a trend that has now reached some Latin American cities. These include increasing automobile pollution and accidents, sedentary life styles, the rise in obesity and diabetes, increased social isolation, and the breakdown of social capital 49. By considering urban health beyond the inner city, this approach raises important questions related to sustainable infrastructure development and the health of populations in sprawling, densely populated metropolitan areas. However, the urban sprawl approach overlooks the inner city as a critical focus of interest and by necessity forces attention on one characteristic of urban areas - sprawl - to the detriment of other features of the urban environment that also influence health.

The "urban health advantage" perspective emphasizes the health benefits of city living. Some data show that health indicators are not only better in urban than rural areas (especially in less wealthy nations) but that the urban poor fare better than the non-urban poor 50 . For example, the infant mortality rate (per 1,000 live births) for the combined areas of North Africa, sub-Saharan Africa, Asia, and Latin America using the Demographic and Health Surveys (DHS) were 86 for rural areas, 75 for the urban poor, and 56 for the urban non-poor. Similarly, height-for-age z-scores among children 3 to 36 months of age, by residence and poverty status using the DHS in these same regions were 173.51 for all rural children; 145.43 for the urban poor; and 109.37 for urban non-poor 50 . These indicators suggest that even when controlling for poverty, health in cities is better than in nonurban areas. What accounts for this "urban health advantage"? The proximity of affluence might contribute to the overall advantage even for the poor by providing clout to secure resources essential to well-being. More affluent members of society not only serve as "bridges" to politicians, government agencies, and sources of outside funding, but can provide a stronger base (and volunteers) for civic and other community-based activities. Wen et al. 51, in 2003, found that measures of neighborhood affluence were positively associated with health even after adjusting for neighborhood-level poverty, income inequality, aggregated educational attainment, and lagged levels of neighborhood health. Thus, socioeconomic heterogeneity, one of the hallmarks of cities, may bring a variety of urban resources such as education and health care within the reach of disadvantaged urban residents. Unlike rural villagers, the urban poor may have access to diverse sources of advice and support that can help them gain access even to unfamiliar sources of assistance. Finally, cities offer the potential for political mobilization and social movements, another possible route to an urban health advantage 52 .

The fourth and final approach seeks to integrate previous frameworks by focusing on “urban living conditions", which are viewed as the day-to-day life circumstances of city dwellers, both health promoting and health damaging, as shaped by global, national, and local factors. In the past few years, urban health researchers have paid more attention to the urban environment in its totality, and a few frameworks have been proposed that describe how features of urban living may affect population health. While some of these frameworks are tightly focused on a single dimension, e.g., how features of the built physical environment may affect population health 49,53,54 others have proposed a framework that considers urban health in the larger context 55. This ecological conceptual framework views health in cities as a function of individual factors influenced by local social and physical environments, including health and social services, which in turn are influenced by municipal factors including local government, civil society, and market forces, national policies, and global trends such as immigration, the changing role of government, and international trade 56 . Researchers debate whether urban health in and of itself is a valid field of inquiry 38,57,58. We argue, however, that the growing importance of cities, coupled with the demonstrated historic and current relations of various features of the urban context and population health, suggest that focused attention on urban health has the potential to guide interventions (with rigorous evaluations) that can dramatically improve the health of populations in the $21^{\text {st }}$ century. We offer below three questions that may help focus urban health research.

\section{Three key questions on how cities affect health}

Modern research methods have allowed greater refinement on the question of how city living and urbanization may (or may not) affect health. However, a review of the scientific research on the relation between urban living and health 
often shows conflicting results. For example, while higher rates of mental illness have been documented in urban compared to rural areas in the United Kingdom 59 urban-rural differences in mental health have not been observed in Canada 60 even though the studies used comparable methodology. In the U.S., some studies have documented urban-rural differences in mental health 61 while others reported no differences 62. A study in Taiwan found a lower prevalence of mental health problems in urban compared to rural areas 63 . Studies of the prevalence of heart disease and cancer by urban versus rural regions have also shown inconsistencies 64 .

Such comparisons however, suffer from the oversimplification of what likely is a complicated relationship. Cities surely affect health, but the net relationship between cities and health is likely to be a combination of a range of factors. For example, living in a particular city brings with it multiple factors, some that affect health adversely, some positively. Thus, a particular city may have more violence and air pollution than surrounding areas but also better social supports and social services. Clearly then, considering how a "city" may affect overall individual "health" is a simplification of a larger and more complicated question. Elsewhere we have discussed these issues more fully 55 . Here we raise key questions to guide future research on health in cities.

\section{What are the specific features of cities that are causally related to health?}

Previous work on urban health has often compared the health of persons in urban and nonurban areas, or alternately, the health of persons in different cities. This work isolates the city itself as the entity of interest and helps identify the characteristics of the city as a whole that may be associated with population health. Although this research has been useful historically, it does not allow a nuanced understanding of the urban characteristics that may be the actual determinants of health. In contrast, the "intra-urban" perspective, a field that has attracted recent attention, considers variations in urban characteristics associated with health. It focuses on spatial groupings of individuals, typically conceived as "neighborhoods", and considers the role of community of residence within an urban area on individual health $65,66,67$. The growing use of multilevel modeling techniques in epidemiology, which allows researchers to disentangle effects due to individual versus neighborhood characteristics, has made these studies both more common and methodologically more robust, and provides an opportunity for deeper insights into how features of the urban environment may influence health. Empirical studies of relative deprivation in developing-country cities are not yet common. Szwarcwald et al. 68, in 2002, showed that neighborhood-level poverty was associated with infant mortality in Rio de Janerio, Brazil. Separately, researchers compared urban and rural India and found that community levels of women's education (and measures of their autonomy) have a significant influence on child mortality rates with household factors held constant 69 . Kaufman et al. 70, in 2002, reported similar methods and results in urban South Africa. By allowing the identification of features of the urban environment that are (perhaps causally) associated with poor health, these studies can suggest avenues for intervention.

\section{To what extent are these features unique} to a particular city or differ between cities?

Identifying the characteristics of urban areas that are associated with health is a first step in understanding the determinants of population health in cities. A necessary, but not sufficient, next step is assessing the extent to which these characteristics are generalizable across cities, permitting generalizable inference and eventually, intervention. A primary drawback to multilevel analyses that evaluate the relation of intra-urban differences to health is that it may be difficult to generalize findings from one city to urban areas more broadly. For example, a London study that found that the physical quality of residences is inversely associated with the likelihood of depression among urban residents 65 may not be relevant in another urban context where other features of the social environment (e.g., social networks, civic organizations) play an equally important role in shaping individual mental health. Given this complexity, variability and the limitations of extant methods in fully assessing how urban living conditions affect health, it will be important for researchers and practitioners to have access to a catalog of observations detailing how specific characteristics of the urban physical and social environment shape health and how these observations extend to different urban contexts. To accomplish this goal, researchers must consider both the context in which their studies were carried out and discuss the extent to which this context is generalizable. For example, investigations that consider how quality of neighborhood housing shape asthma mor- 
bidity 71,72 should also examine the role of medical and preventive care for asthma in a given city. These suggestions are particularly important in the global context, where the primary determinants of health in cities may vary substantially cross-nationally. Assessing the extent to which particular associations between urban characteristics and health are generalizable suggests the need for researchers to think beyond a typical "risk factor" model, where individual risk factors, albeit potentially at multiple levels, are considered in relation to particular diseases. Although such an approach inevitably complicates both the design of the research as well as its interpretation, several epidemiologists have called for a greater appreciation of complexity in epidemiologic research 73,74 and the generation of causal inference 75 . Such considerations are particularly important in the study of urban health.

\section{To what extent are these features} modifiable?

Although urban health researchers seek to describe how city living affects health, ultimately the goal of public health is to improve well-being. In circumstances where multiple factors may contribute equally to the causation of health and disease, it is particularly important to focus inquiry on the potential for intervention to improve health in cities. Each of the four previously described approaches to urban health suggests avenues for intervention at different levels of social organization (e.g., individual, neighborhood, municipality). In one sense, all features of the urban context are to some extent modifiable. However, this generalization belies the fact that specific features may be more easily modifiable, with far greater, relatively short-term improvement in urban population health, than others. For example, the observation that a substantial proportion of morbidity in a given urban area is associated with poor sanitation and inadequate clean water supply, problems that are commonly key determinants of health in developing world cities, may strongly suggest focused interventions that are achievable given an infusion of adequate resources 76,77 . Conversely, the observation that social norms related to substance use place specific urban populations at risk for drug abuse and dependence may require a far larger commitment in the form of a multi-level intervention to affect lasting change 78 . In the final analysis, researchers can make an important contribution to improving urban health by providing policy-makers and practitioners with the evidence needed to select a portfolio of interventions that balance short- and long-term, proximate and fundamental, and categorical and comprehensive approaches to health promotion.

\section{Conclusion}

As cities grow worldwide and as more of the world's population is living in cities, there has been a return of interest in city living and how it may affect health. However, there exists little consensus about the best approach to considering urban health research and what questions such a field of inquiry should address. We suggest that considering urban health in its totality, and particularly focusing on the social, economic, and physical characteristics of cities that affect health has the potential to improve our understanding of population health in cities and to guide effective interventions. Considering the key questions presented here may be a useful guide for academic researchers and practitioners interested in understanding the determinants of health in urban populations. 


\section{Resumo}

A maioria da população mundial irá residir em cidades dentro de alguns poucos anos e a velocidade de urbanização continuará acelerada mundialmente nas próximas décadas. Projeta-se que o número de megacidades aumentará, embora o maior crescimento populacional deverá ocorrer naquelas cidades com um milhão ou menos de habitantes. Esta importante transição demográfica poderá ter enorme impacto sobre a saúde das populações. Embora historicamente sempre tenha havido interesse e compreensão do impacto do urbano sobre a saúde das pessoas e populações, um modelo teórico e sistematizado para estudar a saúde urbana, no tempo e espaço ainda é necessário. Quatro abordagens complementares para o estudo da saúde urbana são discutidas (urban health penalty, urban health advantage, urban sprawl, $e$ an integrative urban conditions model) seguidas por três questões que podem subsidiar o estudo e prática da saúde urbana nas próximas décadas.

Cidades; Urbanização; Saúde Urbana

\section{Contributors}

D. Vlahov conceived, designed, and drafted the manuscript. S. Galea and N. Freudenberg revised for critical important content. All authors reviewed and approved the final manuscript.

\section{References}

1. Brockerhoff MP. An urbanizing world. Pop Bull 2000; 55:3-4.

2. United Nations. World urbanization prospects. The 1999 revision: data tables and highlights. New York: United Nations, Department of Economic and Social Affairs, Population Division; 2000.

3. Butler EB. Women and the trades, Pittsburgh, 1907 1908; the Pittsburgh survey; findings in six volumes. New York: Charities Publication Committee; 1909.

4. Faris REL, Dunham HW. Mental disorders in urban areas. Chicago: University of Chicago Press; 1939.

5. Evans RG, Stoddart GL. Producing health, consuming health care. Soc Sci Med 1990; 31:1347-63.

6. Blum HL. Planning for health: developmental application of social change theory. New York: Human Sciences Press; 1974.

7. Travis JW. Wellness for helping professionals. $3^{\text {rd }}$ Ed. Mill Valley: Wellness Associates; 1977.

8. Vlahov D, Galea S. Urbanization, urbanicity, and health. J Urban Health 2002; 79 (4 Suppl 1):S1-S12.

9. Krupat E. Cities and people. Cambridge: Cambridge University Press; 1985.

10. Grob GN. The deadly truth: a history of disease in America. Cambridge: Harvard University Press; 2002.

11. Power H, Sheard S, Power HJ, editors. Body and city: histories of urban public health. London: Ashgate; 2001.

12. Lund VK. The healthy communities movement: bridging the gap between urban planning and public health. http://www.asu.edu/caed/proceedings99/LUND/LUND.HTM (accessed on 25/May/ 2005).

13. McMichael AJ. Urbanisation and urbanism in industrialised nations, 1850-present: implications for health. In: Schell LM, Ulijaszek SJ, editors. Urbanism, health, and human biology in industrialised countries. Cambridge: Cambridge University Press; 1999. p. 21-45.

14. Glaab CN, Brown TA. A history of urban America. London: Collier-Macmillan Ltd.; 1967.

15. Peters J. Urbanism and health in industrialised Asia. In: Schell LM, Ulijaszek SJ, editors. Urbanism, health and human biology in industrialised countries. Cambridge: Cambridge University Press; 1999. p. 159-63.

16. Lee L. The current state of public health in China. Annu Rev Public Health 2004; 25:327-39.

17. Hamlin C. Public health and social justice in the age of Chadwick: Britain 1800-1854. Cambridge: Cambridge University Press; 1998.

18. Marsella AJ. Urbanization, mental health and psychosocial well-being: some historical perspectives and considerations. In: Harpham T, Blue I, editors. Urbanization and mental health in developing countries. Aldershot: Avebury; 1995. p. 3-14.

19. Durkheim E. The division of labor in society 1893. New York: The Free Press; 1947.

20. Tonnies F. Community and society: gemeinschaft und gesellschaft. East Lansing: The Michigan State University Press; 1957.

21. Dickens C. David Copperfield. London: Harper \& Brothers; 1850. 
22. Engels F. The condition of the working class in England. Stanford: Stanford University Press; 1968.

23. Griscom J. Sanitary condition of the laboring population of New York. New York: Harper \& Brothers; 1845.

24. Sretzer S. Rethinking McKeown: the relationship between public health and social change. Am J Public Health 2002; 92:722-5.

25. Vogele JP. Urban infant mortality in Imperial Germany. Soc Hist Med 1994; 7:401-25.

26. Linden E. The exploding cities of the developing world. Foreign Affairs 1996; 75:52-65

27. Tabibzadeh I, Liisberg E. Response of health systems to urbanization in developing countries. World Health Forum 1997; 18:287-93.

28. Sawaya AL, Dallal G, Solymos G, Sousa MH, Ventura ML, Roberts SB, et al. Obesity and malnutrition in a shantytown population in the city of São Paulo, Brazil. Obes Res 1995; 3 Suppl 2:107S-15S.

29. Uauy R, Monteiro CA. The challenge of improving food and nutrition in Latin America. Food Nutr Bull 2004; 25:175-82.

30. Lozano R, Murray C, Frenk J. El peso de las enfermedades en México. In: Hill K, Morelos JB, Wong $\mathrm{R}$, editors. Las consecuencias de las transiciones demográfica y epidemiológica en América Latina. México DF: El Colegio de México; 1999. p. 130.

31. Hijar M, Trostle J, Bronfman M. Pedestrian injuries in Mexico: a multi-method approach. Soc Sci Med 2003; 57:2149-59.

32. Frenk J, Londoño JL, Knaul F, Lozano R. Latin American health systems in transition: a vision for the future. In: Bezold C, Frenk J, McCarthy S, editors. 21st century health care in Latin America and the Caribbean: prospects for achieving health for all. Alexandria: Institute for Alternative Futures/México DF: Fundación Mexicana para la Salud; 1998. p. 109-42.

33. Grant E. State of the art of urban health in Latin America, European Commission funded concerted action: "Health and human settlements in Latin America”. London: South Bank University; 1999.

34. Barata RB, Ribeiro MC, Guedes MB, Moraes JC. Intra-urban differentials in death rates from homicide in the city of Sao Paulo, Brazil, 1988-1994. Soc Sci Med 1998; 47:19-23.

35. Heise LL, Raikes A, Watts CH, Zwi AB. Violence against women: a neglected public health issue in less developed countries. Soc Sci Med 1994; 39:1165-79.

36. World Health Organization. Investing in health research and development: report of the ad hoc committee on health research relating to future intervention options. Geneva: World Health Organization; 1996.

37. World Health Organization. The World Health Report 2001. Mental health: new understanding, new hope. Geneva: World Health Organization; 2001.

38. Harpham T. Urban health: a future focus for career development. J Urban Health 2004; 2:168-70.

39. Harpham T. Urbanization and mental health in developing countries: a research role for social scientists, public health professionals and social psychiatrists. Soc Sci Med 1994; 39:233-45.

40. World Development Report, 2000/2001. Attack- ing poverty. New York: Oxford University Press; 2001.

41. Trumper R, Phillips L. Give me discipline and give me death: neoliberalism and health in Chile. Int J Health Serv 1997; 27:41-55.

42. De La Barra X. Poverty: the main cause of ill health in urban children. Health Educ Behav 1998; 25: 46-59.

43. Freudenberg N, Galea S, Vlahov D. Beyond urban penalty and urban sprawl: back to living conditions as the focus of urban health. J Community Health 2005; 30:1-11.

44. Wasylenki DA. Inner city health. CMAJ 2001; 164: 214-5.

45. Wilson WJ. When work disappears: the world of the new urban poor. New York: Knopf; 1996.

46. American College of Physicians. Inner-city health care. Ann Intern Med 1997; 127:485-90.

47. McCord C, Freeman H. Excess mortality in Harlem. N Engl J Med 1990; 322:173-7.

48. Geronimus AT, Bound J, Waidmann TA, Colen CG, Steffick D. Excess mortality among Blacks and Whites in the United States. N Eng J Med 1996; 335:1552-8.

49. Frumkin H. Urban sprawl and public health. Public Health Rep 2002; 117:201-17.

50. Montgomery MR, Stren R, Cohen B, Reed H, editors. Panel on urban population dynamics. Cities transformed: demographic change and its implications in the developing world. Washington DC: National Academies Press; 2003.

51. Wen M, Browning CR, Cagney KA. Poverty, affluence, and income inequality: neighborhood economic structure and its implications for health. Soc Sci Med 2003; 57:843-60.

52. Mayer M. The onward sweep of social capital: causes and consequences for understanding cities, communities and urban movements. Int J Urban Reg Res 2003; 27:110-32.

53. Northridge ME, Sclar ED, Biswas P. Sorting out the connections between the built environment and health: a conceptual framework for navigating pathways and planning healthy cities. J Urban Health 2003; 80:556-68.

54. Schulz A, Northridge ME. Social determinants of health and environmental health promotion. Health Educ Behav 2004; 31:455-71.

55. Galea S, Freudenberg N, Vlahov D. Cities and population health. Soc Sci Med 2005; 60:1017-33.

56. Freudenberg N, Galea S, Vlahov D, editors. Urban health: cities and the health of the public. Nashville: Vanderbilt University Press; in press.

57. Vlahov D, Galea S. Urban health: a new discipline. Lancet 2003; 362:1091-2.

58. Guyer B, Gibbons MC. Urban health: discipline or field - does it matter? J Urban Health 2004; 2:165-8.

59. Paykel ES, Abbott R, Jenkins R, Burgha TS, Meltzer H. Noise exposure and public health. Environ Health Perspect 2002; 108 (1 Suppl):123-31.

60. Parikh SV, Wasylenki D, Goering P, Wong J. Mood disorders: rural/urban differences in prevalence, health care utilization, and disability in Ontario. J Affec Dis 1996; 38:57-65.

61. Blazer D, George LK, Landerman R, Pennyabcker M, Melville ML, Woodburgy M, et al. Psychiatric disorders; a rural/urban comparison. Arch Gen 
Psych 1985; 42:651-6.

62. Blazer DG, Kessler RC, McGonagle KA, Swartz MS. The prevalence and distribution of major depression in a National Community Sample: The National Comorbidity Survey. Am J Psych 1994; 151:979-86.

63. Hwu H-G, Yeh E-K, Chang L-Y. Prevalence of psychiatric disorders in Taiwan defined by the Chinese Diagnotic Interview Schedule. Acta Psychiatr Scand 1989; 79:136-47.

64. Yamamoto S, Watanabe S. Geographic characteristics and mortality profiles in the JPHC study. Japan public health center-based prospective study on cancer and cardiovascular diseases. J Epidemiol 2001; 11 (6 Suppl):S8-23.

65. Weich S, Blanchard M, Prince M, Burton E, Erens B, Sproston K. Mental health and the built environment: cross-sectional survey of individual and contextual risk factors for depression. Br J Psychiatry 2002; 180:428-33.

66. Reijneveld SA. Reported health, lifestyles, and use of health care of first generation immigrants in The Netherlands: do socioeconomic factors explain their adverse position? Epidemiol Com Health 1998; 52:298-304.

67. Yen IH, Kaplan GA. Neighborhood social environment and risk of death: multilevel evidence from the Alameda County Study. Am J Epidemiol 1999; 149:898-907.

68. Szwarcwald CL, Andrade CLT, Bastos FI. Income inequality, residential poverty clustering and infant mortality: a study in Rio de Janeiro, Brazil. Soc Sci Med 2002; 55:2083-92.

69. Kravdal Ø. Community mortality in India: Individual and community effects of women's education and autonomy. Honolulu: East-West Center; 2003. (East-West Center Working Papers, Population Series, 112).
70. Kaufman CE, Clark S, Manzini N, May J. How community structures of time and opportunity shape adolescent sexual behavior in South Africa. New York: Population Council; 2002. (Policy Research Division Working Paper 159).

71. Hynes HP, Brugge D, Osgood ND, Snell J, Vallarino J, Spengler J. Where does the damp come from? J Public Health Policy 2003; 24:401-26.

72. Simon PA, Zeng Z, Wold CM, Haddock W, Fielding JE. Prevalence of childhood asthma and associated morbidity in Los Angeles County: impacts of race/ethnicity and income. J Asthma 2003; 40:53543.

73. Koopman JS, Lynch JW. Individual causal models and population system models in epidemiology. Am J Public Health 1999; 89:1170-4.

74. Krieger N. Epidemiology and the web of causation: has anyone seen the spider? Soc Sci Med 1994; 39:887-903.

75. Cordray DS. Quasi-experimental analysis: a mixture of methods and judgments. New Directions in Program Evaluation 1986; 31:9-28.

76. Checkley W, Gilman RH, Black RE, Epstein LD, Cabrera L, Sterling CR, et al. Effect of water and sanitation on childhood health in a poor Peruvian peri-urban community. Lancet 2004; 363:112-8.

77. Heller L, Colosimo EA, Antunes CM. Environmental sanitation conditions and health impact: a case-control study. Rev Soc Bras Med Trop 2003; 36:41-50.

78. Kaplan CP, Napoles-Springer A, Stewart SL, PerezStable EJ. Smoking acquisition among adolescents and young Latinas: the role of socioenvironmental and personal factors. Addict Behav 2001; 26:531-50.

Submitted on 22/Dec/2004

Approved on 07/Jan/2005 